\title{
Changes in gender relations in advertisement show on formula milk in television
}

\section{Perubahan relasi gender dalam tayangan iklan susu formula di televisi}

\author{
Arizal Mutahir \\ Department of Sociology, Faculty of Social and Political Sciences, Universitas Jenderal Soedirman \\ Address: Jalan Profesor DR HR Boenyamin No.708, Banyumas, Central Java 53122 \\ E-mail: arizal_mutahir@yahoo.com
}

\begin{abstract}
In addition to selling products, formula milk advertisements also displayed an overview of what, who, and how is the Indonesian children's identity. The process of constructing a gender perspective of Indonesian children occurred through the representation of children in these advertisements. This paper sought to read advertisements on formula milk in connection to gender relations. The purpose of this paper was to find out how the identity and gender of Indonesian children represented in formula milk advertisement. The constructionist approach used in this paper. Roland Barthes's semiotic method used to read the child's description and the child's gender relations represented in the ad. The data of this paper were 45 adverts of formula milk from eight different brands that aired on television throughout 2011. In the reading process, it revealed that the description of gender roles in formula milk advertisements was a new form of gender relations in Indonesia. In advertisements, there was a mother figure who is still concerned with domestic roles. However, the boundary between domestic space and public space had been fading. The appearance of men had undergone modifications. Fathers were displayed interacting with his children in a friendly manner. This change in appearance did not necessarily change gender stereotypes. Boys were still dominant. They showed as healthy and smart. It had implications for gender ideas that were embedded and expressed in the appearance of children. Boys showed preparing to stare at the future with all the advantages attached to them. Children who showed advertisements of formula milk are boys who look contemporary, creative and come from the middle class.
\end{abstract}

Keywords: formula milk advertisements; changes in gender relations; child representation; boy; girl

\begin{abstract}
Abstrak
Iklan-iklan susu formula selain menjual produk, juga menampilkan gambaran mengenai apa, siapa, dan bagaimana identitas anak Indonesia. Proses konstruksi gambaran tentang gender anak Indonesia terjadi melalui representasi anak dalam iklan-iklan tersebut. Tulisan ini berupaya membaca iklan-iklan susu formula berkenaan dengan relasi gender. Tujuan tulisan ini mengetahui bagaimana identitas dan gender anak Indonesia direpresentasikan dalam iklan susu formula. Pendekatan konstruksionis digunakan dalam tulisan ini. Metode semiotik Roland Barthes digunakan guna membaca gambaran anak dan relasi gender anak yang terepresentasikan dalam iklan. Data tulisan ini adalah sebanyak 45 iklan susu formula dari delapan merek yang tayang di televisi sepanjang tahun 2011. Dalam proses pembacaan, terungkap gambaran peran gender dalam iklan-iklan susu formula merupakan sebentuk gambaran baru tentang relasi gender di Indonesia. Dalam iklan-iklan dijumpai sosok ibu yang masih berkenaan dengan peran domestik, namun batas antara ruang domestik dan ruang publik telah cair. Tampilan lelaki telah mengalami modifikasi. Ayah ditampilkan lebih akrab berinteraksi dengan anak. Perubahan tampilan itu, tidak serta merta mengubah stereotipe gender. Anak lelaki ditampilkan masih dominan. Mereka ditampilkan sehat dan pintar. Hal itu berimplikasi terhadap gagasan gender yang disemaikan dan terekspresikan dalam tampilan anak. Anak lelaki ditampilkan bersiap diri menatap masa datang dengan segala keunggulan yang dilekatkan pada mereka. Anak yang ditampilkan iklan-iklan susu formula adalah anak lelaki berpenampilan kekinian, kreatif dan berasal dari kelas menengah.
\end{abstract}

Kata kunci: iklan susu formula; perubahan relasi gender; representasi anak; anak lelaki; anak perempuan

\section{Introduction}

Formula milk advertisements that aired on television, in addition to selling products, also displayed a Figure of what, who, and how is the identity of Indonesian children. The process of constructing a Figure of the gender of Indonesian children took place through the representation of children in these advertisements. Goffman (1979:10-23) called advertising is a Figure of reality. According to him, reading advertisements was the best way to see the relationship between parents and children. For 
him, the relationship between parent and child was not much different from the relationship between women and men. Advertisement description on the relationship between parents and children and the relationship between men and women was an 'expected' Figure by society. This Figure derived from the existing cultural resources in society. Therefore the Figure contained in the advertisement was not very foreign to us as the audience. In the end, the audience assumed the description in the advertisement as their own story.

For Goffman, that was the persuasive power of advertising. Advertisement not only described how we behave but also illustrated how everything should be. Williamson (2007:7) argued that advertisement promoted a vision of how everything should be. Jhally (1989:225) mentioned that advertisement always offers a vision of a new identity. This offer claimed as a better identity. The advertising industry recognised that selling products means selling identities. The idea of a new identity was synonymous with new being, "new me". "The new look is the same as the new me," wrote Jenkins (2008:14). Therefore, the image contained in advertising unconsciously became a human reference (Gittins 2009:36). He mentioned that the advertisement Figure was one of several things that can show more broadly about the feelings and experiences and how memories presented.

The series and linkages of various images, including images contained in advertisements, formed an idea that becomes a reference in addressing and even assessing various things or events. Based on the ideas summarised from various scattered images, humans generally point at and refer to simultaneously. It included a description of children and their world. However, the notion of children only confined to age differences. While, the figure of children and their world, historically and sociologically, was extensive. It involved many categories in society. The formation of a child's world was not just a matter of age difference. Shaping the children's world was also about gender and class differences. The concept of a child's world that only based on age differences gave an impression that all children are the same, generally accepted and universally identical (Gittins 2009:36). It was eliminating their world rather than revealing it. Besides, it also ignored the fact that the meaning and assumptions within the world of children constructed by certain social groups, but then used to define the whole family and all children. Moreover, seeing children under mere age differences perspective further hid the class, ethnicity and gender differences found in their world (Gittins 2009:35). Thus, seeing children and their world cannot be based solely on age categories. They were especially looking at them and their world as displayed in advertisements.

In the advertisement, various images presented how to be a child, how to treat a child, and how to behave like a child. Advertisements sometimes portrayed children and their world in a very concise, stylish and excessive way. However, some of these images, both rejected and accepted, are involved in shaping ideas about the world of children. The formation of a child's image also used as a form of self-memory; for society, parents, and of course person, namely individuals who have children. Therefore, the description of children and their world in advertisements did not always contain bright and rational matters but also contained hopes, desires and emotions. Thew (2002:138-139) called the world of children, like the world of adult humans, was a construction battlefield, a change and debate about identity. The formation of a child's identity was similar to the identity of an adult that continues to shape and reshape, inseparable from interactions with the adult human world which are embedded by various categories, one of which is gender (Thew 2002:138-139).

Based on the facts above, this paper discussed children's image portrayed in formula milk advertisements by linking it to gender categories, first, by identifying the gender relations within formula milk advertisements. The purpose was to observe feminine and masculine depictions in formula milk advertisements concerning the relationship between parents and children. It based on the opinion that changes in gender relations within the adult world would affect children's image (Budgeon 2014:330). In the context of children's world, what happened in the adult world would affect the family. What happened in the family, both directly and indirectly, consequently affected the children themselves (Jensen \& McKee 2003:2-3). This influence seen in the child's response toward changes occurred across his life journey. Family, according to de Vaus (2012:30), is very much formed by gender relations. When gender relations formed in the family changes, such as the role of father and mother, the overall gender construction also changes. 
This paper is essential to be written due to several considerations. Firstly, ideas within society are inseparable to the context of community development. Even though this paper limited by time, space is still discussed. Therefore, the discussion was not only about the year 2011 when formula milk advertisements were displayed, but also space where diverse ideas of Indonesians crossed within. Despite 13 years gap between the formula milk advertisements reviewed in this article and the end of the New Order, it is undeniable how traces of the past are still noticeable. Secondly, in 2011 the government through the Ministry of Health began implementing a ban on the advertisement of formula milk (Tempo 2010). This ban deemed as the beginning of the formation of a new discourse on Indonesian children. Thirdly, in 2011 the government also began implementing the 2010-2014 Community Nutrition Development Action Plan. One indicator of the performance of community nutrition development is exclusive breastfeeding. This program is, assumed in this paper, in contrast to the discourse developed by the formula milk industry. The government, for example, issued Presidential Regulation No. 40 of 2011 concerning Coaching, Assistance, and Recovery of Children Who Become Victims or Perpetrators of Pornography. One of its clauses is the protection of children from the media. It is following shortly after was the issuance of the Regulation of the Minister of Women Empowerment and Child Protection of the Republic of Indonesia No. 03 of 2011 concerning Child Participation Policy in Development and Minister Regulation PP\&PA No. 12 of 2011 concerning Indicators of Regency/City for Children. Fourthly, in 2011 there was a prolonged controversy regarding the announcement of the research on formula milk brands contaminated with Enterobacter Sakazakii (ES) bacteria (Kompas.com 2011). Various events assumed in this paper that the discourse about children involved many parties and many interests.

\section{Research Method}

Data collected through observation and documentation techniques. First, the observation by watching commercial television programs (RCTI, SCTV, MNCTV, Indosiar, AnTV, TVOne, MetroTV, TransTV, Trans7, and GlobalTV) on the two primetime hours of children programs; from 06.00 until 10:00 and from 14.00 until 16.00 WIB. The observation was more often done on Sundays and holidays. On those days, every television station usually increased children's broadcast hours and producers introduced new products through advertisements that allowed more comprehensive data collection. At the time of observation, each formula milk advertisement appeared was recorded with a laptop USB TV recorder and logged the advertised product to a single folder based on the product name.

Formula milk advertisements in this paper were treated as 'artefacts' to see children and their world. As an artefact, there were various languages in formula milk advertisements. Hall's (2000) representation theory stated that meaning produced through language. Language is a sign system from which various real or abstract realities, events, objects represented. Formula milk advertisements mostly featured children as their main actors. Thus, the Figures and writings used in formula milk advertisements were texts that consisted of a sign system producing specific meanings about numerous children's identities. For this writing, the semiotic method used to answer questions about the issue of children's representation in advertisements. It departed from the opinion that semiotics as a study of the sign system thas the ability to decipher the meaning of the sign system within formula milk advertisement. The approach used was the semiotics model developed by Barthes (1972). It put more emphasis on expressing the 'other' meanings in the text and were carried out through the second-degree semiotics method. This paper assumed that the meanings contained in formula milk advertisements could not only be read as mere literal meanings. Images and writings in formula milk advertisements presented sure signs, codes and ideologies.

\section{Result and Discussion}

S'Amore (2012:1226) mentioned that advertisements that feature tough women who did not lose their feminine nature was getting common. These types of advertisements no longer described the super-mama, namely women who can handle private and public spaces at the same time, as possessing superhuman abilities. In short, women can do housework and at the same time, earn additional income for the family economy. The appearance of women as super-moms was replaced by advertisements which are more about how gender roles commonly found in society. 
Studies on gender categories in advertising mentioned that stereotypes of gender roles in advertising had begun to diminish slightly. It means, according to Robinson \& Hunter (2008:471), stereotypes about gender were still ongoing, namely advertisements that described men as breadwinners and women as housewives. However, the gender roles that appeared in advertisements were becoming increasingly 'realistic' (Espinar-Ruiz \& Gonzalez-Diaz 2012:109-126). Some advertisements had included images of women who did not only manage the household. They showed to be in public spaces and doing work that were generally considered as men's job. Conversely, portray men doing work that generally considered to be women's work, was increasing.

In the context of formula milk advertisements, several advertisements had featured women who were active in public spaces - women in advertisements described as independent and in power. Independent women in formula milk advertisements were attractive because formula milk products claimed themselves as the provider of children's health and care (Page \& Brewster 2007:332). Caring is often associated with femininity. In the traditional view, that characteristic placed women in the domestic space. What showed in formula milk advertisement tended to fight against the traditional view of gender roles. Some portrayals of women in formula milk advertisements were no longer related to domestic work. Even in the professional field, some formula milk advertisements showed women working in the formal sector. In some advertisements, women showed as professional workers. The Bebelac 3 formula milk advertisement titled 'Everyday is Mother Day', at least showed the trend of advertisements that portrayed women working in the formal sector.

This advertisement below showed an office worker who is raising a 3-year-old child. The portrayal of the mother as a worker can see in her working clothes and bag. The activities carried out as well as the room setting that indicated a workspace or office. Working in an office required relatively high education. The display in this advertisement showed that women could be highly educated and appeared in public spaces. It showed that women have power and are independent.

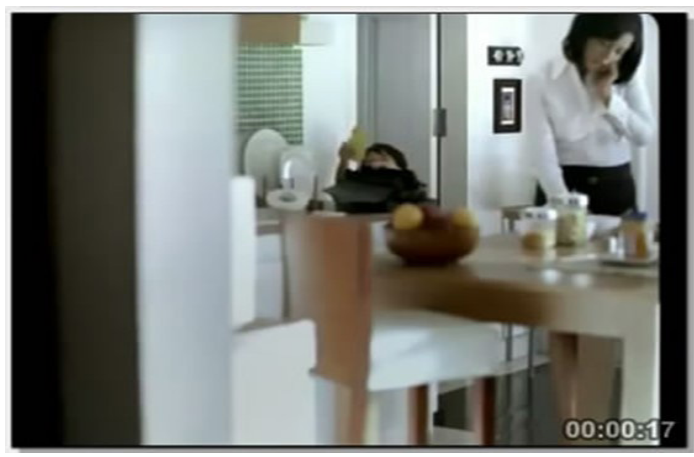

Figure 1.

Everyday is Mother Day

What found in the Bebelac 3 advertisement might not be surprising, but the feminine element immediately embedded the independence of women in the initial appearance. The advertisement headline had emphasised that mothers are still mothers; they are mothers every day despite having to work outside the house. In the advertisement, the independence of women expressed in the segment where women are on the phone while taking notes (Figure 1). That scene could be interpreted as doing something important. Some appointments or messages must be noted and done immediately. Making an appointment and taking notes could be interpreted as making a decision. Deciding when and where the appointment should be and making work-related decisions must be done immediately or postponed. There was an active and independent impression portrayed in the scene. According to Giddens (1991:70-75), the woman was building a consistent feeling about biographical sustainability. Every moment, she interrogated herself in terms of what was happening. That was a Figure of modern humans.

Feminine nature of the advertisement was seen in the makeup of the woman. Shoulder-length hair, long-sleeved shirt and black skirt already gave the impression of her feminine nature. The feminine nature is further strengthened by the forehead kissing scene of the child and the display of heart 
figure with the words' love' in the card the child made. The heart shape and the word 'love' are mostly identical in the opinion of the general public. The word love considered to be more feminine than masculine. The advertisement also showed that although women work in the public sector, they do not abandon domestic matters. It can be seen from the background setting where a dining table was next to the sink with a row of plates next to the tub. There was a fruit basket, white bread and several jars filled with jam and snacks on the table. A dining table is a place where all family members met and shared stories while eating. The activity of eating together emphasised the attitude of togetherness rather than hostility. The scene at the dining table in the advertisement showed harmony, a family warmth commonly found in the domestic space. In the advertisement, the appearance of the domestic space strengthened by the appearance of the child's card with the house Figure with the words' "Luv mom" attached to the mother's workspace (Figure 2).

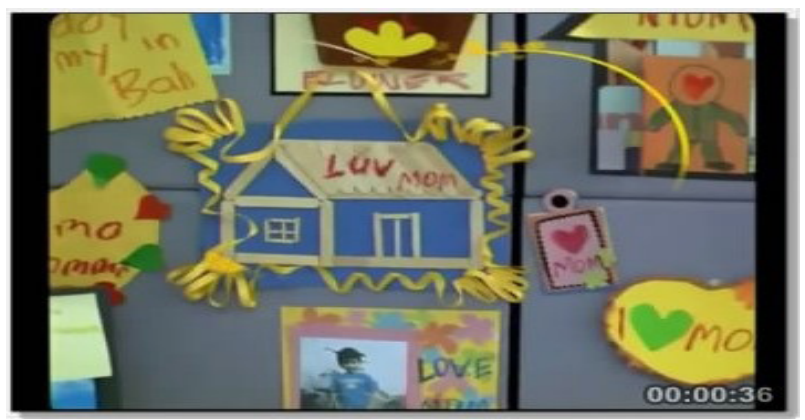

Figure 2.

Everyday is Mother Day

The house Figure scene was displayed using the zoom-in technique as if to emphasise that the house is still prominent nonetheless. In the scene, the house Figure card was centred, surrounded by other Figure cards. Home is not just a place to live. For most Indonesians, home is a place to return, a place of inner bonding that formed, developed and nurtured. The house had emotional and psychological aspects of uniting its residents (Newberry 2013:17-19). In the advertisement, the technique of zooming-in to the image of the house about showing that family is of the utmost importance. Although the mother worked in a public space, she did not forget her role as a housewife. There was a link between women's position in domestic and public space. Since the beginning of the scene, the advertisement had featured women in a dual space, domestic and public. The appearance of a woman in a white shirt and black skirt which was on the phone while taking notes in the dining room showed the merging of two realms into one. In that scene, two realms appeared in one scene simultaneously. Formula milk is the bridge connecting the two worlds; the link between domestic space and public space.

This Bebelac 3 advertisement was trying to deliver the message that women can be more than just homemakers. The task of caring for and raising children can still be done by a woman even though she also holds a role in public space. Women in this advertisement showed as active women. However, their feminine nature not eliminated. It was even more emphasised. Therefore, women can still look feminine despite working in the public sector. As parents, the woman in this advertisement looked perfect. She did two tasks at the same time. This advertisement carried a myth about perfect parents. The appearance of the female figure also showed that the boundaries of domestic and public spaces had been dissolved. Women can have a career and at the same time, do their obligations as parents in nurturing their children. The dissolved boundary separating domestic and public spaces can also be found in formula milk advertisements titled 'Earn Your Tomorrow'.

Through flashback storytelling technique, the advertisement 'Earn Your Tomorrow' unfolded the story of a father's struggle as narrated by his child. In this advertisement, audiences followed the portrayal of a man selling fried rice around. He did job to make ends meet for his family. Specifically, for the sake of his children's future. To achieve that goal, he went through numerous obstacles. In the advertisement, it described how he faced the rain while doing his job. Through his child's narration, his father portrayed as a hard worker. Because of that, the child wanted to be like his father. 
The formula milk advertisement "Earn Your Tomorrow" displayed a son's memories of his father. A hardworking father who strived for his children's future. The depiction of men as hard workers in Indonesia would not be much different from the norms found in society. According to Kurniawan, Indonesian men have a burden to bear household needs (Nilan, Demartoto, \& Broom 2013:5). It had become a type of masculinity imposed on Indonesian men. This distinctive trait of masculinity was the power over economic resources through working or having employment. This type of masculinity required a man to be able to take care of household needs by himself. Otherwise, he would be embarrassed and deemed as an incapable man by society. In the advertisement, one of Indonesia' masculinity models was portrayed through a hardworking man. He was willing to work as a fried rice seller to make ends meet for his family (Figure 3). For the general public, this type of work is not a desirable employment choice.

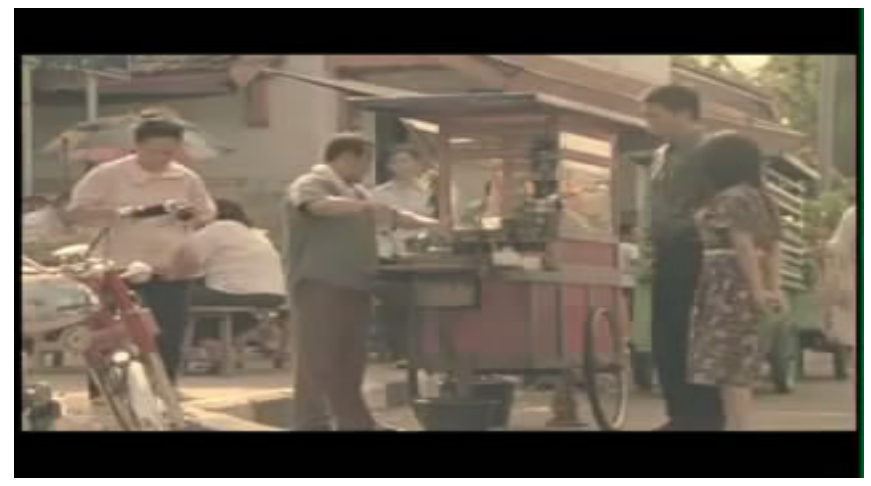

Figure 3.

Bendera's ‘Earn Your Future’ Advertisement

In Indonesia, fried rice sellers often classified as street vendors or Pedagang Kaki Lima (PKL). They often referred to as informal workers. In 2011, there were 68.2 million informal workers in Indonesia (Berita Resmi Statistik 2011:3). Their average income in a month was equal to or below the regional/ provincial minimum wage or Upah Minimum Regional (UMR). Based on 2011 data, the Special Capital Region of Jakarta had the highest UMR in Indonesia at IDR 1.29 million per month (Badan Pusat Statistik 2015) while Central Java was the province that had the lowest UMR in Indonesia at IDR 675.000. Based on the World Bank's definition of middle-class income, street vendors do not belong to this group (Kementerian Keuangan Republik Indonesia 2015). According to the World Bank, middle income in Indonesia ranged from IDR 2.6 million to IDR 5.2 million per month. In the advertisement, father portrayal as a fried rice seller much highlighted to show how a man works hard to make his child better off than himself in terms of economic life. The man in the advertisement described as trying to work hard for economic life through his fried rice cart and fried rice carts are moved and controlled by physical force. It showed that men could both encourage and control the family economy. That cart was the family's source of income. A man controlled the source of income.

The advertisement 'Earn Your Tomorrow' showed a man's efforts to become 'capable' to support his family regardless of the type of work undertaken. Fried rice sellers highly involved cooking. In public view, cooking is deemed as an activity carried out by women. In Javanese culture, for example, there are terms of masak (cooking), macak (grooming), manak (giving birth). Those three words refer to the women's role in a household. The term described the domestic role that must be undertaken by a woman (Arimbi 2009:61-612). In the advertisement, the cooking was carried out by men in order to make a living. When carried out by men outside the home, domestic activities are viewed differently. When women make fried rice at home, it is not considered as a work. However when a man does it outside the house, he is getting paid for it. Moreover, it is considered as a job. In the advertisement, the job used by the man to show that he was 'capable' and loving the family at the same time. It also spread myths about the power of men to support, to give attention and affection for children simultaneously. The power wrapped by love for the family.

In the advertisement "Earn Your Tomorrow", a form of love and attention of men to the family displayed through a scene where the man was waiting for his son drinking his milk at the dinner 
table (Figure 4 and Figure 5). As previously mentioned, the dining table was a symbol of family harmony. It further strengthened by the appearance of a woman, the wife, who was watching the man waiting for the child to drink milk in a single frame display. Through this scene, the advertisement symbolised milk as a form of love and attention from a father toward his son. Other scenes reinforced this message. In the advertisement, there was a scene where the father carried the child, protected the child from dog attacks, accompanied the child studying to sleep, observed the child in class and more importantly, provided the best for the child, through the provision of milk. All of those activities were the form of attention and affection of a father.

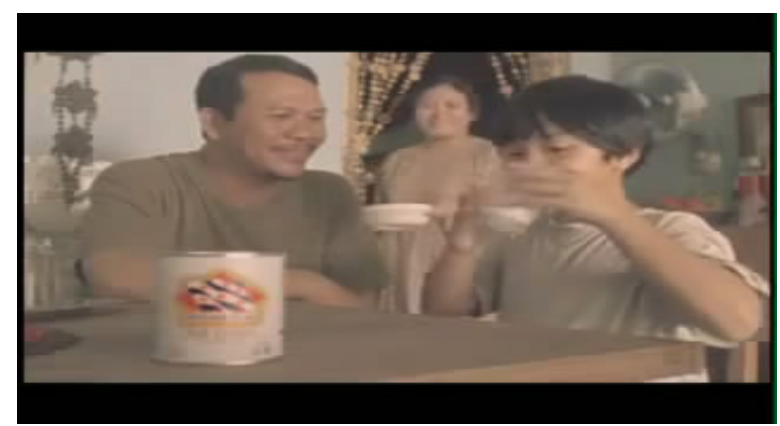

Figure 4.

'Earn Your Tomorrow' Advertisement

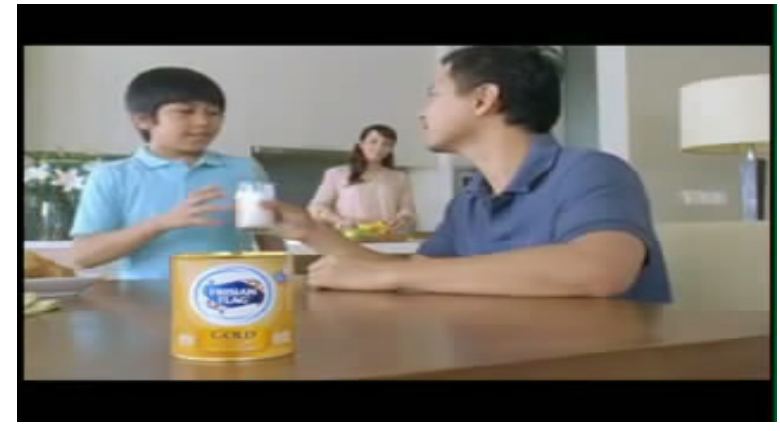

Figure 5.

'Earn Your Tomorrow' Advertisement

Scenes shown in this advertisement were different from the standard advertisement display on parents' love toward their children. Affection and attention to children shown in advertisements generally portrayed through scenes with women. Often, men as fathers, according to Robinson \& Hunter (2008:477) were shown alone without the presence of a child. However, in the advertisement 'Earn Your Tomorrow' the father was described as being considerate of his child. In this advertisement, gender stereotypes seemed to be fading. Macionis (Tylor 2003:304) mentioned that there are several stereotypes that often arise on feminine and masculine roles. Masculine stereotypes are always associated with healthy, brave and active in nature hile feminine stereotypes are generally weak, caring and passive. In advertising, masculine stereotypes are usually attached to male roles, while feminine stereotypes are attached to female roles. Affection and attention tend to be feminine rather than masculine, but in the advertisement it was conveyed by the father role. In this advertisement, the gender stereotype boundaries commonly found in advertisements featuring female and male roles were already flexible. According to Cortese (2008:69-75), the appearance of affectionate or even awkward men who complies to women's demand in an advertisement is in accordance with the product value promoted. Advertisement targeting women as market would place men as an attentive figures solely to attract the attention of women, namely mothers who are their main consumers target. Cortese's opinion is reasonable. Roberts \& Pettigrew (2007:369) stated that formula milk advertisement is under food and beverages advertisement category.

Most advertisements of this kind target women. Thus, the main target of formula milk advertising is women (Aronovsky \& Furnham 2008:171). Specifically, women who have children under five years old. The presence of men in the advertisement 'Earn Your Tomorrow' presented alternative 
masculinity about an existing male image in Indonesia. Previously, the image of strong men was very dominant (Nilan, Demartoto, \& Broom 2013: 6). Strong men are men capable of anything. He can do everything but is indifferent to his children's development and his family. Strong men merely fulfil their responsibilities as breadwinners. The portrayal of a hardworking father who loved and cared for the family in the advertisement gave a different idea of the real male masculinity.

The loving man image broadcasted in the 'Earn Your Tomorrow' advertisement further emphasised on the closing scene of this advertisement (Figure 5). In the advertisement, the scene followed the son of the fried rice seller giving milk to his son. The narrator's monologue went; "Now it is my turn," which showed that the man in the scene was the son of the fried rice seller. The child who idolised the father. The child who had managed to achieve a better life because a compassionate and loving man raised them. Because of that, he wanted to recreate what his father had done to his child. This advertisement disseminated myths about perfect parents. Perfection as a parent in this advertisement strongly emphasised through the scene of fathers giving milk to boys in two different scenes with a different actor and setting (Figure 4 and Figure 5).

Comparing the background setting, the scene fried rice-selling father (Figure 4) and the scene of the kid selling fried rice (Figure 5) were similar, a dining table with a female figure watching a man give milk to his child. The position of the cast was still the same, and the father sat while giving a glass of milk, the boy stood up while receiving a glass of milk and the mother who stood watching. What distinguished the two scenes was the appearance of the actor and the different space interior. Judging by their clothes, the actors showed different social classes. In Figure 4, the clothes worn by the father were a plain T-shirt while in Figure 5 the clothes of the father were collared polo shirts. Meanwhile, the mother in Figure 4 was seen wearing a dull sleeping gown with simple makeup while in Figure 5, the mother was wearing a fashionable suit. T-shirts and sleeping gown indicated lower social class, which is in contrast with the polo shirts and suits that commonly portrayed upper-middle-class appearance.

The portrayal of class differences can also be seen from the interior and some home furnishings. In Figure 4, some handicraft accessories on the door and wall of the house were visible. Then there were some home furnishings such as utensils and flasks located in the corner of the room. The most prominent was the existence of a fan hanging on the corner wall of the room. The room did not appear neat. Space accessories and household furniture were randomly scattered to fill the space. The room looked small and cramped. The distance between the mother stood watching the father giving milk to the child looked close. Even the distance between the siting father and son looked very close.

In Figure 5, the space interior was different. The room appeared to be neat and tidy. There were not many furniture in the room. Lamp in the corner behind the father, refrigerator and AC (air conditioning) found in the corner of the kitchen room behind the mother's position stood did not look out of place. Arrangement of home furniture seemed to be decorated by a professional. The room looked spacious and open. The distance between the mother stood watching the father giving milk to the child looked far away. Even the distance between the sitting father and son left a relatively ample space.

Judging from the room layout, the two scenes in the advertisement 'Earn Your Tomorrow' displayed class differences. Both showed a family room in an urban area. The fan and AC indicated it in each room. In Indonesia, indoor heat tends to be more common in urban areas. Fans and air conditioners aimed to cool down the room. The price of $\mathrm{AC}$ is about ten times more high than the price of a fan. The fan is in the room in Figure 4 The existence of the fan to indicate lower social class reinforced by the cramped room and chaotic spatial decoration due to space. Figure 5 . showed different spatial conditions. The presence of air conditioning and a neater, more spacious room already indicated the atmosphere of an upper-middle-class family room.

The two contrasting images displayed on the 'Earn Your Tomorrow' advertisement reflected a class bias within the ad. Class differences simultaneously indicated a gender bias in it. Overall the advertisement was about conveying that loving man had successfully deliver a better life to his children. It was demonstrated through the father's attention to the child by giving milk for his son to 
drink. While the mother just watched as a bystander. Those scene portrayed in two different frame containing social class differences. Through those two scenes, the advertisement reinforced the gender bias that had taken place in all layers of social class in the society that the role of women is only limited to the kitchen or domestic matters. In the two scenes, it showed that the mother only watched the interaction between her husband and her child. However, the class and gender biases in the advertisement were subtle because it was trying to show the ideal way to take care of children. It was as if the class differences and gender biases did not exist in the advertisement. All these differences were seen as natural, healthy and conventional.

Through the display of two different scenes, it also found that children's view possessed particular value for their parents. Children were no longer seen as helpers for parents' jobs but rather understood in an emotional context, which was more effective than calculative. In this advertisement, there was no more extended image of children that economically profitable and supportive. Father was shown as a hard-worker for his children instead. Children become priceless emotionally. In other words, children were considered as 'useless' and 'worthless' economically (Fass 2012:457).

Based on Bebelac 3 formula milk and 'Earn Your Tomorrow' explained previously, the gender role contained in formula milk advertisements no longer conformed to the traditional ideology in commonly found in advertisement. In those two advertisements, gender roles were exchanged. In the Bebelac 3 advertisement, women were shown capable to work in public spaces. While the man in the 'Earn Your Tomorrow' advertisement showed able to do domestic work. Both can exchange places and even be presented as one. In terms of the feminine side, the portrayal of women who were active but not losing their feminine side still persisted in formula milk advertising.

Meanwhile, in terms of masculinity shown by formula milk advertisement, there was a slight change. The man shown in the formula milk advertisement was shown as concerned about child caring. Fathers were shown to have no distance when dealing with children. Then about the description of social class in society, the existence of social classes in advertisements was more likely to tell stories about the middle class. Although in the advertisement 'Earn Your Tomorrow' there was a scene of fried rice sellers, but the scene was a part of series about the struggle of fathers told by children who have had occupied a better social standing than his father.

The most salient point found on those two adverts was that family remained the top priority. In the Bebelac 3 advertisement, it showed through the kissing scene and the display of a house Figure card. While in the advertisement "Reach Your Tomorrow", it was shown through the scene of carrying a child and watching him study. They also showed differences in the parents-children relationship in two different advertisements - the difference between how men and women relate to children. There were different behaviour of men and women in displaying their affection. It also indicated that there were differences in the parent-children relationship.

The description of the relationship between parents and children in Indonesia had undergone some changes. During the New Order, the study of Farver \& Wimbarti (1995:1493) showed the relationship of parents-children in Indonesia as limited. Parents' interactions were not very intimate. Parents were seen as calm, restraint and hiding their emotions. It made children awkward and stiff when dealing with their parents. Shiraishi (1996:226) mentioned that family culture placed children in the lowest position and under the control of parents. To communicate was to command. Children must obey their parents. There was no opportunity for children to ask, let alone discuss what parents said and commanded. This image slowly changed after the Reformation in 1998. Spyer (2003) stated that during the beginning of the Reformation, Indonesian children began to have their hopes and imagination when dealing with their parents. Strassler (2006:53-70) mentioned that children obtained a special place in their relationship with their parents. Children were free to express themselves. White (2012:8197) stated that the results of that freedom made children dare to refuse what their parents asked.

In the advertising world, the portrayal of parents-children relationships also changed. Previously, advertisements generally featured male figures who were emotionally distant from children. Clark 
(2004:27) mentioned that after the Reformation of the parents-children relationship in advertisements, a more sensitive and involved male figure were shown interacting closely with children. The involvement here still showed some distance in the father-children relationship because the advertisements still displayed father-children relationships in public spaces outside houses, instead of domestic spaces. If the relationship looked close, the advertisements appeared more humorous.

Clark's description was a little different to formula milk advertisement context. In formula milk advertisements, the relationship between parents and children was shown to be more friendly and even intimate. Often, fathers and mothers were involved with children's activities in the home. The advertisement 'Indomilk's Sweet Condensed Milk Drummer version', displayed the relationship between parents and children in the house (Figure 6).

This 'Drummer' advertisement tried to show warmth in the family. The family shown in the broadcast was the nuclear family consisted of mother, father and child. In the nuclear family, the primary duty of parents in raising and caring for children (Bengston 2001:9, Morgan 2014:9). In the advertisement, a warm interaction was taking place inside the house. A neat and comfortable middleclass house and reading while sitting on a sofa in a neat house did not indicate lower class family that this advertisement was showing. The scene where the woman stood behind the father and son while doing something showed that gender role stereotypes still applied. The mother was busy preparing something for the father and son who were chilling on the sofa. The scene seemed to illustrate that the mother's job was to serve the needs of her husband and care for children. Judging from the colours of clothes worn by fathers and mothers, it seems that gender stereotypes are increasingly attached to the actors. The father wore blue clothes, while the mother wore pink.

Two colours of clothes worn by the father and mother, in the field of product marketing are often used as a product indicator when sorting out a target market. The blue colour is used for the male target market, while the pink colour used for the target market for women. In its development, the two colours became the colour of gender (Panarese 2015:340). According to Buckingham (2007:20), the two colours become polarised. Those engaged in marketing do not want to take the risk of changing colours when selling packaged products. Moreover, the polarisation between the blue world and the pink world further reinforced in advertisements. Blue is the colour of male; pink is the colour of female.

In the 'Drummer' advertisement, the dominant figure in the family room can be spotted. The father always answered every question the child asked. Through this advertisement, it seemed that the description of Indonesian men who tend to be calm and distant from children (Farver \& Wimbarti 1995:1493-1503, Shiraishi 1996:226, Arimbi 2009:61-62) was nowhere to be found. In this advertisement, the father can answer all questions from the child. Fathers in advertisements were not portrayed as silent and distant. He talked a lot compared to mother. Mother only chimed in the words of the child. The scene also showed that men are still positioned as the center of the family. In the advertisement, the role of the man was not merely looking after family economy, he had also been emotionally involved in child-rearing and parenting. Father had a friendly chat with the child. The scene in the house shows how intimacy is happening. According to Clark (2004:27) there were many advertisements in Indonesia featured scenes of child and parent relations taking place outside the home previously. It made the relationship between parent and child seemed distant. In the advertisement, intimacy was seen through the face of the father, who was always happy every time he answered the child's question. The father was open and friendly to the child. Openness also showed the father's position. Father became a person who knew everything, was affectionate and was the protector of the family. It can be seen in the scene where the father answered the child's question about how to become a soldier (Figure 6.).

Following the scene of the father answering the child's question, the father's left hand caressed the child's head, while the right hand raised in a fist in front of the child. The left hand was a supporting and encouraging stroke the father was always behind his child while the right hand in fist showed both enthusiasm and authority that the father was in charge. Father has the authority over the family. The display of authority was also seen by emphasising the answer, "Must be disciplined and keep on 
practising." The word discipline and practice is a narrative building process within the child itself. In the language of Giddens (1991:27) children are taking action to arrange their life trajectory and anticipate the future. The father showed the way, which was by being disciplined and to practice all the time. The process of forming a child's self in the advertisement involved the father. With the words 'must' and 'discipline' that father said, it seemed that the process of self-reconstruction was underway in the family. The father was in charge as a mentor as well as a protector for the child.

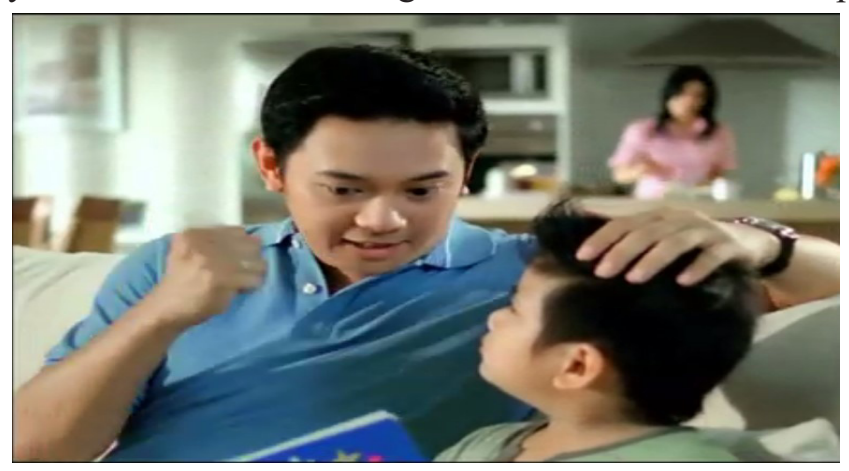

Figure 6.

'Indomilk's Drummer' Advertisement

Image of the father as mentor and child protector found in the scenes of fathers and children drinking milk in the advertisement and the scene placed the child in front while the father was behind him in the frame. There was no hand touching involved in the scene. The position of the father behind, showed provision of protection (Goffman 1979:39). Fathers support each child's decision because ultimately, what the child does is the result of parental upbringing. The scene of a father and son drinking milk showed that child drinking milk was a result of parents' education. In the context of advertising, fathers appeared more dominant when teaching to drink milk, even though mothers made the drinks and outlined the benefit of drinking milk.

The 'Drummer' advertisement showed direct involvement of parents in caring and educating their children. Children's questions about the type of work indicated how education took place in the family. This is different from the findings of Zevalkink and Riksen-Walraven (2001:170-171) when observing the relationship between father and child in Indonesia. According to them, the relationship between father and son in Indonesia still uses an authoritarian approach. This approach still severely limits interactions with children, fathers tend to be repressive and even punitive. In the advertisement, the father was highly involved in teaching his children something.

Further, the learning process displayed in the advertisement was a democratic type of education (Baumrind 2013:11-12). In the advertisement, this was displayed when the kid was joking:

"Continuous training is exhausting, Dad..."

The child complains, albeit done in a joking manner, as a form of argument that was replied by the father with a smile while holding the child's head. Even the mother gave a solution to her son's complaints, which is to drink milk.

Children's behaviour to raise complains to their parents, according to White (2012:81-97) began to emerge after the Reformation. Thus, what portrayed by the 'Drummer' advertisement was not new in terms of how the relationship between children and parents changes. Relationships built have begun to show an egalitarian attitude so that the child dared to refuse the parents' demand. In fact, in the advertisement, the child's decision to have a different kind of dream was responded with a smile by both parents. At the end of the story, it showed that the child wanted to be a drummer. Music often referred to as a means of self-expression and even rebellion. In this advertisement, the child's choice responded with a smile from his father and mother. Children are allowed to know new things. This image is different to the description of Parker (1992: 116) when he saw Indonesian children during the New Order era where children were not allowed to try things that will make them go against parents. 
The attention of the father toward his child stood out the most in the 'Drummer' advertisement. In all advertisements, the portrayal of fathers with their children were dominant. Listening to the questions and answers session between father and son in the advertisement, it was clear that the work asked by the child was more masculine. Astronauts and soldiers are often considered men's job; it advertisement seemed to illustrate the socialisation of masculinity within the family. This masculinity was further emphasised when we paid attention to the actors. Father answered son's questions about what jobs are considered to be male's. The masculinity side of the child was also identified in his haircut. His haircut was a spike style. A spike-style haircut was a pointy stick up with side of the head cut short, not shaved off. Characteristic of the spiky hairstyle is a thick front side to make it looks like a crest. Spike haircuts gives off manly look impression which shows more masculine side (Watania 2015). This haircut style began to get popular in Indonesia in 2002 and became a trend in 2011 because Justin Beiber, an American celebrity, popularised this style that was then labelled as Justin Bieber spike (Adystiani 2011). The child in the advertisement 'Drummer' was not only showing masculinity in his appearance but also showed that the child is following the trends. The advertisement also displayed an ideal appearance through its actors.

Considering the number of actors used in the advertisement, Goffman's description of the ideal family image in advertising might have changed. Goffman (1979:37) mentioned that advertisements showing families tended to display a pair of father-mother and a pair of son-daughter as an ideal Figure of a whole nuclear family. In the formula milk advertisement explained previously, it showed a small number of a family member. An Indonesian family profile report showed that the average number of person per family in Indonesia had decreased every year. The report noted that the average number of person per family in 2011 was 3.68 people per family. This figure is slightly lower compared to the 2010 average of 3.69 people per family (Badan Kependudukan dan Keluarga Berencana Nasional 2013: 22). Hull (2006: 184) stated that this condition was one of the results of a two-child-is-enough campaign coupled with the use of contraception.

The portrayal of the family in the 'Drummer' advertisement showed a supportive husband and wife relationship toward their child's dreams. Even though both of them did not have any conversation, the mother's replies to the child's dialogue on their dreams showed that what the father's words were supported by the mother. The husband and wife in the advertisement built an interaction through their son's question on his dream. Giddens (1992:154-155) mentioned that along with the development of a modern family, marital relations are built through togetherness and empathy toward each other during interaction within the family. The interactions described in the advertisement were warm and intimate. This friendliness was manifested in drinking milk. At this point, the 'Drummer' advertisement was disseminating a myth about intimacy in the middle class even though it contradicted the fact that parents in middle-class families in Indonesia spend more time outside the home to make a living for their family.

\section{Conclusion}

Based on the analysis of formula milk advertisements, it found that they spread a myth about perfect parents. Women, as mothers, showed as active women. However, the feminine nature was not eliminated, and it even more emphasised. Despite working in the public sector, women can still look feminine. As parents, women in advertisements looked perfect. They did two tasks at once, became career women as well as parenting.

In formula milk advertisements, the gender roles displayed were no longer adhering to traditional ideologies. Gender roles had been exchanged. Women were displayed working in public spaces. While men showed to be able to do domestic work, both could exchange places and even be presented as one. In terms of the feminine traits, the portrayal of active women without losing their feminine side persisted in formula milk advertising. While in terms of the masculinity displayed, there was a slight change. Men had been shown as attentive figures in caring for their children. Fathers showed to have no distance when interacting with their children. 
The most salient point was family as the top priority. Family intimacy highlighted in formula milk advertisements. Previously, many advertisements in Indonesia displayed scenes of children and parents relations outside the home, which gave the impression of distant family relations. In formula milk advertisements, the relationship between parents and children showed to be more friendly and even intimate. Often, fathers and mothers were involved with children's activities in the home. Relationships built had begun to show the egalitarian attitude of parents towards children so that children also dared to refuse what parents asked. In some advertisements, supportive husband and wife towards children's dream displayed. Children who were prepared to chase their future. They are boys who were portrayed in a trendy, creative style and came from the middle class.

\section{References}

Adystiani (2011) 5 model rambut paling ngetrend di 2011. Tabloid Bintang, 28 December. [Accessed 2 February 2018]. https://archive.tabloidbintang.com/gaya-hidup/kesehatan/19360-5-modelrambut-paling-ngetren-di-2011.html.

Arimbi DA (2009) Reading Contemporary Indonesian Muslim Women Writers, Representation, Identity and Religion of Muslim Women in Indonesian Fiction. Amsterdam: Amsterdam University Press.

Aronovsky A \& Furnham A (2008) Gender portrayals in food commercials at different times of the day: A content analytic study. Communications 33:171.

Badan Kependudukan dan Keluarga Berencana Nasional (2013) Profil Hasil Pendataan Keluarga Tahun 2012. Jakarta: BKKBN Direktori Pelaporan dan Statistik.

Badan Pusat Statistik (2015) [Accessed 30 April 2015]. https://www.bps.go.id/linkTableDinamis/ view/id/917.

Barthes R (1972) Mythologies. New York: Hill and Wang.

Baumrind D (2013) Authoritative Parenting Revisited: History and Current Status. In: Robert EL, Amanda SM \& Amanda WH (ed) Authoritative Parenting: Synthesizing Nurturance and Discipline for Optimal Child Development. Washington DC: American Psychological Association USA, pp. 11-12.

Berita Resmi Statistik (2011) No. 74/11/Th. XIV, 7 November 2011, 3.

Bengston VL (2001) Beyond nuclear family: The increasing importance of multigenerational bonds. Journal of Mirrage and Family 63:4.

Buckingham D (2007) Selling childhood? Children and consumer culture. Journal of Children and Media 1 (1):20.

Budgeon S (2014) The dynamics of gender hegemony: Femininities, masculinities and social change. Sociology 48 (2):330.

Clark M (2004) Indonesian masculinities: Images of men in Indonesian TV advertising. Review of Indonesian and Malayasian Affairs 38 (2):27.

Cortese AJ (2008) Provocateur: Image of Women and Minorities in Advertising. New York: Rowman \& Littlefield Publishers.

de Vaus D (2012) Social Trends and Their Impact on Couple and Family Relationships. In: Noller P \& Karantzas G (ed). The Wiley-Blackwell Handbook of Couples and Family Relationships. Oxford: Blackwell Publishing Ltd., pp. 30.

Espinar-Ruiz E \& Gonzalez-Diaz C (2012) Gender portrayals in food commercials: A content analysis of Spanish television advertisements. Observatorio Journal 6 (4):109-126.

Farver JAM \& Wimbarti S (1995) Indonesian children's play with their mothers and older sibling. Child Development 66 (5):1493-1503.

Fass P (2012) Vivian Zelizer. Giving meaning to the history of children. Journal of History of Childhood and Youth (v5.3):457. 
Giddens A (1991) Modernity and Self Identity. Self and Society in the Late Modern Age. Cambridge: Polity Press.

Giddens A (1992) The Transformation of Intimacy. Sexuality, Love and Eroticism in Modern Societies. California: Stanford University Press.

Gittins D (2009) The Historical Construction of Childhood. In: Kehily MJ (ed). An Introduction of Childhood Studies. New York: Open University Press, pp. 36.

Goffman E (1979) Gender Advertisements. New York: Harper Torchbooks.

Hall S (2000) Representation: Cultural Representations and Signifying Practices. London, Sage.

Hull TH (ed) (2006) Masyarakat, Kependudukan dan Kebijakan di Indonesia. Jakarta: Equinox Publishing.

Jenkins R (2008) Social Identity Key Idea. New York: Routledge.

Jensen A \& McKee L (2003) Theorising Childhood and Family Change. In: Jensen A \& McKee L (ed). Children and the Changing Family. Between Transformation and Negotiation, New York, RoutledgeFalmer, pp. 2-3.

Jhally S (1989) Advertising, Gender and Sex: What's Wrong with a Little Objectification? EnParmentier R \& Urban G (eds). Working papers \& proceedings of the Center for Psychosocial Studies, pp. 225.

Kementerian Keuangan Republik Indonesia (2015) [Accessed 30 April 2015] http://www.bppk. kemenkeu.go.id/publikasi/artikel/167-artikel-pajak/21014-penghasilan.

Kompas.com (2011) Polemik Enterobacter Sakazakii. http://lipsus.kompas.com/topikpilihanlist/ $1153 / 1 /$.

Morgan DJH (2014) Social Theory and The Family. New York: Routledge.

Newberry J (2013) Back Door Java: Negara, Rumah Tangga dan Kampung di Keluarga Jawa, terjemahan BE Sumarah dan M Maris. Jakarta: Yayasan Obor Indonesia.

Nilan P, Demartoto A, \& Broom A (2013) Masculinity, violence and socioeconomic status in Indonesia. Culture, Society \& Masculinities 5 (1):5.

Page RM \& BrewsterA (2007) Emotional and rational product appeals in televised food advertisements for children: Analysis of commercials shown on US broadcast networks. Journal Child Health Care 11 (323):332.

Panarese P (2015) Selling gender. The representation of boys and girls in Italian toy commercials. Italian Journal of Sociology of Education 7 (3):340.

Parker L (1992) The Quality of Schooling in Balinesse Village. Indonesia 54:116.

Roberts M \& Pettigrew S (2007) A thematic content analysis of children's food advertising. International Journal of Advertising 26 (3):369.

Robinson BK \& Hunter E (2008) Is mom still doing it all? Re-examining depictions of family work in popular advertising. Journal of Family 29:471.

S'Amore LM (2012) The accidental supermom: Superheroines and maternal performativity 19631980. The Journal of Popular Culture 45 (6):1226.

Shiraishi SS (1996) The birth of father and mother in Indonesia classroom. Journal Southeast Asia Studies 34 (1):226.

Spyer PE (2003) "'Belum Stabil:" Some Signs of the Time in Post-Soeharto Indonesia. Conference at Universitas Indonesia, August 2003. Jakarta.

Strassler K (2006) Reformasi through our eyes. Children as Witnesses of History in Post-Soeharto Indonesia. Visual Anthropology Review 22 (2):53-70.

Thew N (2002) Race, Class and Gender. In: Mills J \& Mills R (ed.) Childhood Studies: A Reader in Perspective of Childhood. New York: Routledge, 138-139. 
Tempo (2010) Pelarangan ini ditetapkan setelah terjadi polemik berkepanjangan pada tahun-tahun sebelumnya. [Accessed 30 September 2011]. tempo.co/read/2010/10122/173286548/TahunDepan-Iklan-Susu-Dilarang.

Tylor F (2003) Content analysis and gender stereotypes in children's books. Teaching Sociology 31 (3):304.

Watania F (2015) gaya rambut spike trend rambut pria tahun 2015. Tribun Manado, 20 February. [Accessed 2 February 2018]. http://manado.tribunnews.com/2015/02/20/gaya-rambutspike-trend-rambut-pria-tahun-2015.

White B (2012) Changing childhoods: Javanese village children in three generation. Journal of Agrarian Change 12 (1):81-97.

Williamson J (2007) Decoding Advertisements: Membedah Ideologi dan Makna dalam Periklanan, terjemahan S Rahmana. Yogyakarta: Jalasutra.

Zevalkink J \& Riksen-Walraven JM (2001) Parenting in Indonesia: Inter and intracultural differences in mothers' interactions with their young children. International Journal of Behavioral Development 25 (2):170-171. 